\title{
The use of pronominal forms in complement clauses in European and Brazilian Portuguese
}

\author{
Paula Luegi ${ }^{1}$, Marcus Maia ${ }^{2}$, Armanda Costa ${ }^{1}$ \\ ${ }^{1}$ School of Arts and Humanities, University of Lisbon, CLUL, Portugal \\ ${ }^{2}$ Federal University of Rio de Janeiro, LAPEX, Brazil \\ https://doi.org/10.36505/ExLing-2019/10/0034/000396
}

\begin{abstract}
In this study, in a written sentence completion experiment, we contrast European and Brazilian Portuguese in what concerns the production of null, overt pronouns and full NPs, as subjects of verb complement clauses, to refer to the previously mentioned entities (or to extra-discursive referents). Results show that overall participants prefer to use null pronouns and that these pronouns are preferentially used to refer to the closest NP, especially in BP. Moreover, overt pronouns and full NPs are hardly used, being the later more frequent than the former, especially to refer to extra-discursive referents. Although the preference to refer to the closest subject with the null pronoun is in line with previous studies, high frequency of null pronouns and low frequency of overt ones in $\mathrm{BP}$ is not. We propose that these results might be explained by the characteristics of both the tested conditions and of the participants tested in our study.
\end{abstract}

Key words: European and Brazilian Portuguese, null and over subject pronouns, sentence completion task

\section{Introduction}

Although European and Brazilian Portuguese (EP and BP) share common properties, there are some differences between them, like the null subject parameter: Null subjects are not only less frequent in BP (Duarte 1995, Barbosa et al. 2005), compared to EP, but are also more restricted (Modesto 2018, Holmberg et al. 2009). This is especially true for $3^{\text {rd }}$ person singular pronouns (Duarte \& Figueiredo Silva 2016), the focus of the present study. Holmberg et al. (2009) propose that $3^{\text {rd }}$ person null subjects in partial null subject languages, like BP, must have a local antecedent that c-commands it. This locality effect results in a rejection of co-reference between subjects that are not immediately adjacent, that is, when there is an intervening subject (Holmberg et al. 2009). Also, null subjects cannot refer to extra-discursive referents (that is, not explicitly mentioned). So, in (1) and (2), the antecedent must be João and cannot be Pedro or any other entity.

(1) a. O João disse que [-] comprou um carro.

b. O João disse que ele comprou um carro. "John said that (he)/he bought a car."

ExLing 2019: Proceedings of 10 $0^{\text {th }}$ International Conference of Experimental Linguistics, 25-27 September 2019, Lisbon, Portugal 
(2) O Pedro acha que o João disse que [-] comprou um carro.

"Peter thinks that John said that (he) bought a car."

Moreover, the interpretation of overt pronouns is also different in both varieties: While in EP null subject pronouns are preferentially interpreted as referring to the previous subject and the overt pronouns as referring to nonsubject antecedents, in BP both null and overt subjects might be interpreted as referring to João both in (1a) and (1b).

However, all these descriptions are mainly based on intuitive judgments (see however Modesto (2018)) or in corpora analysis.

\section{Experimental study}

In the present study we conducted an experiment with a written sentence completion task to test the descriptions presented in the previous section. Participants had to complete sentences like (3) and (4).

(3) John said that

(4) Peter said that John knows that

We aimed at: (i) compare the overall frequency of null and overt subjects in EP and in BP, (ii) verify the restrictions of null subjects reference, that is which antecedents are retrieved with null subjects: local, distant (intervening subject) or extra-discursive antecedents, and (iii) verify the differences between EP and BP in overt pronouns production and interpretation.

\section{Participants, materials and procedure}

Twenty eight native speakers of EP, from the University of Lisbon, and 27 native speakers of BP, from the Federal University of Rio de Janeiro, participated voluntarily in this study after accepting the informed consent.

Experimental items, all main sentences with embedded complement clauses selected by the verb, were built in two different conditions: OneReferent condition (ex. (3)) and Two-Referents condition (ex. 4)). Sentences (24 experimental items and 48 fillers) were presented on OnExp one at a time in a randomized order in two lists in a Latin Square design. Participants had to complete the sentence after the word "that" and to answer the question: "Whom or what did you refer in the text you wrote?".

\section{Analysis}

Data was coded as to indicate (i) type of anaphoric expression produced: Null subject, Overt pronoun or full NP, and (ii) mentioned entity: Closest-NP ("John", in (3) and (4)), Distant-NP ("Peter", in (4)), or Extra-NP (Extradiscursive NP) if the referred entity was not in the previous clauses. Linear mixed models with binomial function and full maximal model were used 
considering type of anaphoric expression and mentioned entity as dependent variables in separated analysis.

\section{Results}

When comparing Null subjects with Others (Overt pronouns and full NPs), there is a main effect of Variety (Table 2), with more Null pronouns in BP (Table 1), a main effect of Sentence Type, with more Null pronouns in OneReferent condition, and an interaction of Variety and Sentence Type, with more Null pronouns in One-Referent condition in BP. Contrasts of Null vs. Overt or vs. full NPs replicated these results. When comparing Overt with full NPs, there is a marginal effect of Sentence Type: less Overt pronouns in OneReferent condition (Est. $=-7.972 ; \mathrm{SE}=4.503 ; \mathrm{z}=-1.771 ; \mathrm{p}=0.076$ ).

Table 1. Percentage of answers referring to Closest-NP, Distant-NP or ExtraNP with Null, Overt or full NP in One-Referent (EP: $n=183$; BP: $n=250$ ) or Two-Referents (EP: $n=216$; BP: $n=226$ ) conditions.

\begin{tabular}{|c|c|c|c|c|c|c|c|}
\hline & \multicolumn{3}{|c|}{ One-Referent } & \multicolumn{3}{|c|}{ Two-Referents } \\
\hline & & Null & Overt & full NP & Null & Overt & full NP \\
\hline \multirow{3}{*}{ EP } & Closest-NP & $64 \%$ & $3 \%$ & $0 \%$ & $49 \%$ & $9 \%$ & $0 \%$ \\
\hline & Distant-NP & -- & -- & -- & $1 \%$ & $8 \%$ & $0 \%$ \\
\hline & Extra-NP & $0 \%$ & $1 \%$ & $32 \%$ & $0 \%$ & $0 \%$ & $32 \%$ \\
\hline \multirow{3}{*}{$\mathrm{BP}$} & Closest-NP & $82 \%$ & $2 \%$ & $0 \%$ & $56 \%$ & $6 \%$ & $1 \%$ \\
\hline & Distant-NP & -- & -- & -- & $2 \%$ & $13 \%$ & $0 \%$ \\
\hline & Extra-NP & $0 \%$ & $0 \%$ & $16 \%$ & $0 \%$ & $0 \%$ & $22 \%$ \\
\hline
\end{tabular}

When comparing Closest-NP with all Others (Distant-NP and Extra-NP), there is a main effect of Variety (Table 2), with more references to the Closest-NP in BP, a main effect of Sentence Type, with more references to the Closest-NP in One-Referent condition, and an interaction of Variety and Sentence Type, with more references to the Closest-NP in One-Referent condition in BP.

Overall, participants tend to produce more null subjects than any other expression, especially in BP and in One-Referent condition. In both varieties, null subjects are mainly used to refer to the Closest-NP being the reference to Distant-NPs almost residual. Full-NPs are used especially to refer to extra-discursive entities. There is a very low frequency of overt pronouns, in both conditions and in both EP and BP, being however more frequent in Two-Referents condition to refer to Distant-NPs. 
Table 2. Results of the Linear Mixed Effects analysis.

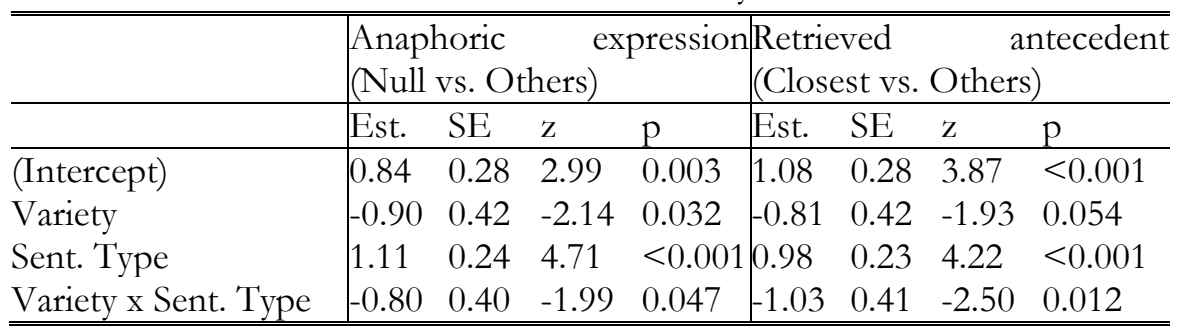

Null subject results are partially in line with previous proposals: Null subjects in BP are mainly used to refer to the Closest-NP (Holmberg et al. 2009, Modesto 2018). However, the high frequency of null subjects and the consequent low frequency of overt pronouns, in BP, is unexpected. This result might be explained by the fact that the conditions are structurally and discursively restricted leading to an increase of null pronouns production, especially in the $3^{\text {rd }}$ person, more resistant to its replacement in BP (Barbosa et al. 2005). Also, or in addition, participants' characteristics might also explain this result: We tested university students, more likely to use the written norm and, therefore, to produce null subjects (see Almor et al. (2017) for similar results in written BP corpora). Further studies are necessary to explore not only the frequency of overt and null pronouns use but also the preference of interpretation of null subjects to retrieve Closest/Distant-NPs in comprehension tasks.

\section{References}

Almor, A., Maia, J.C., Lima, M.L.C., Vernice, M., Gelormini-Lezama, C. 2017. Language processing, acceptability, and statistical distribution: A study of null and overt subjects in Brazilian Portuguese. Journal of Memory and Language 92, 98-113.

Barbosa, P., Duarte, E., Kato, M. 2005. Null subjects in European and Brazilian Portuguese. Journal of Portuguese Linguistics 4:2, 11-52.

Duarte, E. 1995. A perda do princípio "evite pronome" no português brasileiro. PhD dissertation, Universidade Estadual de Campinas.

Duarte, I., Figueiredo Silva, M.C. 2016. The null subject parameter and the structure of the sentence in European and Brazilian Portuguese. In W.L. Wetzels, J. Costa, S. Menuzzi (Eds.), The Handbook of Portuguese Linguistics, 234-253. Hoboken, NJ: John Wiley \& Sons, Inc.

Holmberg, A., Nayudu, A., Sheehan, M. 2009. Three partial null-subject languages. Studia Linguistica, 63(1), 59-97. 